\title{
The Effect of Feet Soaking Using Warm Water with Ginger Aromatherapy to Decrease Blood Pressure on Hypertension Patients in the Working Area of Community Health Center 1 Sumbang Banyumas
}

\author{
$1^{\text {st }}$ Kiki Alfillaturrohman \\ Undergraduate Student of Bachelor of \\ Nursing \\ Faculty of Health Science, Harapan \\ Bangsa University \\ Purwokerto, Indonesia \\ Email: kiki1alfilaturohman@gmail.com
}

\author{
$2^{\text {nd }}$ Tophan Heri Wibowo \\ Nursing Lecturer \\ Faculty of Health Science, Harapan \\ Bangsa University \\ Purwokerto, Indonesia \\ Email: bowo_4@yahoo.com
}

\author{
$3^{\text {rd }}$ Amin Susanto Nursing \\ Lecturer \\ Faculty of Health Science, Harapan \\ Bangsa University \\ Purwokerto Indonesia \\ Email : aminsusanto@uhb.ac.id
}

\begin{abstract}
One way to lower blood pressure is using feet soaking therapy with warm water using a ginger aromatherapy. Soaking parts of the body into the warm water can improve circulation, reduce edema, and improve muscle relaxation, which leads to blood pressure drop. This study aimed to find out whether there is an effect of feet soaking with warm water using ginger aromatherapy to decrease blood pressure on hypertension patients. The method of this research was Quasi-experiment with pre- and post-test design with control group. The instrument used was a sphygmomanometer. This research was carried out for one week by providing therapy for 7 feet of warm water mixed with aromatherapy ginger every morning. The samples were taken using Purposive Sampling which resulted in 20 respondents. The statistical tests used were Wilxocon test and Mann Withney test. The results of this study indicated that the value of the Wilxocon test obtained systolic p-value $=0.004$ and diastolic $p$-value $=$ $0.002, \mathrm{HO}$ is rejected, while the Mann Withney test results obtained systolic p-value $=0.001$ and diastolic p-value $=0.005$ then $\mathrm{HO}$ is rejected, which means that there is an effect of giving therapy of feet soaking with warm water using ginger aromatherapy to decrease blood pressure on hypertension patients. Therefore, this therapy can be used as a companion to medical therapy.
\end{abstract}

Keywords: feet soaking, ginger aromatherapy, blood pressure, hypertension

\section{INTRODUCTION}

Hypertension is a health problem of the people in the world. Based on WHO [1], approximately 972 million people, or $26.4 \%$ of people worldwide suffer from hypertension. This number is likely to increase to $29.2 \%$ in 2025. Based on Basic Health Research in 2013 the incidence of hypertension in Indonesia reached 25.8\%, but in 2018 it increased to $34.1 \%$ [2].
Based on the measurement results of hypertension in the city or regency level, the highest percentage of hypertension occurs in Wonosobo with $42.82 \%$, followed by Tegal with $40.67 \%, 39.55 \%$ in Kebumen, $39.52 \%$ in Banyumas and $39.00 \%$ in Tegal. The city or regency with the lowest percentage of hypertension can be found in Pati with $4.50 \%$, followed by Batang $4.75 \%$. Jepara with $5.55 \%$, Semarang with $7.38 \%$ and Blora with $10.83 \%$ [3].

Based on the data from the Health Office of Banyumas Regency in 2016, it is known that the incidence of essential hypertension are 4963 cases with the highest incidence in the Community Health Center of South Purwokerto as many as 808 cases. The second was ranked by Community Health Center of Sumbang 1 as many as 446 cases. This generation has increased compared to the one in 2015 as many as 4395 cases with the highest incidence in Community Health Center of Cilingok I as many as 538 cases [4].

One way to lower blood pressure is using feet soak therapy with warm water. Soaking parts of the body into the warm water can improve circulation, reduce edema, improve muscle relaxation [5].

Foot soak therapy can help improving blood circulation by widening the blood vessels; so that more oxygen is delivered to the swollen tissues. The refinement of blood circulation also facilitates the circulation of lymph that cleans toxins from the body. The methods commonly used in the implementation of hydrotherapy are soak bathing, hydro massage, sitzbath, wrapping with a wet cloth, compress, and feet soak [6].

Feet soak can be combined with other herbal ingredients such as ginger. The types of ginger known by the society are yellow ginger, rhino ginger, and red ginger, However the 


\section{RESUlTS AND DISCUSSION}

Table 1

contains volatile oil which is higher than other ginger [6].

Ginger contains fat, protein, starch, oleoresin (gingerol) and essential oils. Warm taste and spicy aroma of ginger is caused by volatile oil content and gingerol. Warm taste of can broaden the blood vessels so that blood flows run smoothly [6].

The results of pre-survey conducted by researchers at the Community Health Center of Sumbang 1, seeing the data from the book of ten big diseases, it was found that hypertension ranked the second every year by the total number of patients' visits 4299 in 2018 and this data increased from the total number of patients' visit 3959 in 2017.

The result of the survey conducted by the researchers indicated that resolution of health problems in Sumbang district especially on hypertension issue is not optimal as for health services only provide pharmacological treatment and has not done a health promotion regarding nonpharmacological treatment for hypertension. However people have a habit of using traditional medicine to cure diseases, yet it has not been in accordance with the standard operational procedures of the intervention so that the effectiveness of the use of traditional medicine can't be felt well.

Based on the description above, the researchers are interested in observing the effect of feet soak using warm water with the mixture of ginger aromatherapy to reduce blood pressure on hypertension patients in the working area of community health center 1 Sumbang Banyumas Regency II. PURPOSE

To find out wheather there is an effect of feet soak using warm water with a mixture of ginger aromatherapy to reduce blood pressure in patient with hypertension.

\section{METHOD}

This study used quasi-experimental method with prepost - test design with control group. It is a way to reveal causal relationship by involving the experimental group and the control group [7].

This research was conducted in the working area of Community Health Center 1 Sumbang Banyumas in April 2019. The population was patients with hypertension as many as 385 respondents in Community Health Center 1 Sumbang. The samples were taken using purposive sampling resulting in 20 respondents. They were divided into a control group and experimental group. Data was collected using a sphygmomanometer and a master table.
Table 2

Distribution of blood pressure control group before and after the treatment in patients with hypertension in Working Area of Community Health Center 1 Sumbang Banyumas

\begin{tabular}{llcc}
\hline Blood Pressure & & $\mathrm{N}$ & $\begin{array}{c}\text { Median } \\
(\text { min-max })\end{array}$ \\
\hline Before & Sistolic & 145 \\
& Diastolic & 10 & $(130-160)$ \\
& & & $(90-110)$ \\
\hline After & Sistolic & & 145 \\
& Diastolic & 10 & $(130-150)$ \\
& & & $(90-110)$ \\
& & &
\end{tabular}

Based on Table 2, it shows that the systolic blood pressure before the treatment had a median value of 145 $\mathrm{mmHg}$, a minimum value of $130 \mathrm{mmHg}$ and a maximum value of $160 \mathrm{mmHg}$, while diastolic blood pressure had a median value of $100 \mathrm{mmHg}$, a minimum value of $90 \mathrm{mmHg}$ and a maximum value of $110 \mathrm{mmHg}$. The systolic blood pressure after the treatment had a median value of 145 $\mathrm{mmHg}$, a minimum value of 130 and a maximum value of 150 , while the diastolic blood pressure after intervention had a median value of $100 \mathrm{mmHg}$, a minimum value of 90 $\mathrm{mmHg}$ and a maximum value of $110 \mathrm{mmHg}$. 
Table 3

Distribution of blood pressure in the experimental group before and after the treatment in patients with hypertension in the working area of Community Health Center 1 Sumbang Banyumas

\begin{tabular}{llll}
\hline \multirow{2}{*}{ Blood Pressure } & N & Median (min-max) \\
\hline Before & Systolic & & $\begin{array}{l}150 \\
(140-180)\end{array}$ \\
& & 10 & 110 \\
& Diastolic & & $(100-120)$ \\
\hline After & Systolic & & 130 \\
& & 10 & $(120-140)$ \\
& Diastolic & 90 \\
& & $(80-100)$ \\
\hline
\end{tabular}

Based on Table 3, it shows that the systolic blood pressure prior to the treatment had a median value of 150 $\mathrm{mmHg}$, a minimum value of $140 \mathrm{mmHg}$ and a maximum value of $180 \mathrm{~m} \mathrm{Hg}$, while the diastolic blood pressure prior to the treatment had a median value of $110 \mathrm{mmHg}$, the minimum value of 100 and a maximum value of $120 \mathrm{mmHg}$. The systolic blood pressure after the treatment had a median value of $130 \mathrm{mmHg}$, a minimum value of $120 \mathrm{mmHg}$ and a maximum value of $140 \mathrm{mmHg}$, while diastolic blood pressure had a median value of $90 \mathrm{mmHg}$, a minimum value of $80 \mathrm{mmHg}$ and a maximum value of $100 \mathrm{mmHg}$.

\section{Table 4}

Data analysis of blood pressure using Wilxocon in patients with hypertension in the working area of Community Health Center 1 Sumbang

\begin{tabular}{|c|c|c|c|}
\hline \multicolumn{4}{|c|}{ Banyumas } \\
\hline & Blood Pressure & Mean Rank & p-value \\
\hline \multirow[t]{3}{*}{ Systolic } & Pretest control group & & \\
\hline & Posttest control group & 3.50 & 0.414 \\
\hline & $\begin{array}{l}\text { Pretest experimental } \\
\text { group } \\
\text { Posttest experimental } \\
\text { group }\end{array}$ & 5.50 & 0.004 \\
\hline \multirow[t]{3}{*}{ Diastolic } & Pretest control group & & \\
\hline & Posttest control group & 3.00 & 0.739 \\
\hline & $\begin{array}{l}\text { Pretest experimental } \\
\text { group } \\
\text { Posttest experimental } \\
\text { group }\end{array}$ & 5.50 & 0.002 \\
\hline
\end{tabular}

Based on Table 4, it indicates that systolic blood pressure in control group before and after the treatment had mean rank value of 3.50 with a $p$-value $=0.414(p>\alpha)$, diastolic blood pressure had mean rank value of 3.00 with pvalue $=0.739(p>\alpha)$. The systolic blood pressure in the experimental group before and after intervention had a mean rank value of 5.50 with $\mathrm{p}$-value $=0.004(\mathrm{p}<\alpha)$. Diastolic blood pressure had a mean rank value of 5.50 with $\mathrm{p}$-value $=$ $0.002(\mathrm{p}<\alpha)$.

Table 5

Result of Mann Whitney test in patients with hypertension in working area of Community Health Center 1 Sumbang Banyumas

\begin{tabular}{|c|c|c|c|}
\hline & Blood Pressure & $\begin{array}{l}\text { Mean } \\
\text { Rank }\end{array}$ & p-value \\
\hline \multirow[t]{4}{*}{ Systolic } & Pretest control group 1 & 8.60 & \\
\hline & $\begin{array}{l}\text { Pretest experimental } \\
\text { group }\end{array}$ & 12.40 & 0.134 \\
\hline & Posttest control group & 14.60 & \\
\hline & $\begin{array}{l}\text { Posttest experimental } \\
\text { group }\end{array}$ & 6.40 & 0.001 \\
\hline \multirow[t]{4}{*}{ Diastolic } & Pretest control group & 8.05 & \\
\hline & $\begin{array}{l}\text { Pretest experimental } \\
\text { group }\end{array}$ & 12.95 & 0.044 \\
\hline & Posttest control group & 14.00 & \\
\hline & $\begin{array}{l}\text { Posttest experimental } \\
\text { group }\end{array}$ & 7.00 & 0.005 \\
\hline
\end{tabular}

Based on Table 5, it indicates that systolic blood pressure of pretest in control group had a mean rank value of 8.60 and one in the experimental group had a mean rank of 12.40 with a p-value $=0.113(\mathrm{p}>\alpha)$. Diastolic blood pressure of pretest in the control group had a mean rank of 8.05 and on in the experiment group had a mean rank of 12.95 with a $p$-value $=0.044(p>\alpha)$. While in the research results the systolic blood pressure of post-test in the control group had a

mean rank value of 14.60 and one in the experimental group had a mean rank value of 6.40 with p-value $=0.001$ $(p<\alpha)$. The diastolic blood pressure of posttest in the control group had a mean rank value of 14.00 and diastolic blood pressure of post-test in the experimental group had a mean rank value of 7.00 with $p$-value of $0.005(p<\alpha)$.

V. DISCUSSION

a. Age and Gender

In this research, it was found out that the majority of respondents aged $\geq 56$ years and was dominated by women (90). The incidence of hypertension is likely to increase with age because of decreased elasticity, widening and rigid so that the blood cannnot circulate easily [8].

Gender influences the occurrence of hypertension, in which in the young age under 60 years, men are 
more likely to suffer from hypertension. Men are assumed to have a lifestyle that tends to increase blood pressure. However after entering the menopause, the prevalence of hypertension in women increased. Even after the age of 65 years, the occurrence of hypertension in women is higher than in men. It may be caused by estrogen hormonal factors that can protect women from cardiovascular disease, these hormone levels will decline after menopause [9].

b. Distribution of Blood Pressure in the Control Group Before and After the Treatment in the Working Area of Community Health Center 1 Sumbang Banyumas

In this study the finding shows that the systolic blood pressure before the treatment had a median value of $145 \mathrm{mmHg}$, a minimum value of $130 \mathrm{mmHg}$ and a maximum value of $160 \mathrm{mmHg}$, while the diastolic blood pressure had a median value of $100 \mathrm{mmHg}$, a minimum value of $90 \mathrm{mmHg}$ and a maximum value of $110 \mathrm{mmHg}$.

The systolic blood pressure after the treatment had median value of $145 \mathrm{mmHg}$, a minimum value of 130 and a maximum value of 150 , while the diastolic blood pressure after intervention had a median value of $100 \mathrm{mmHg}$, a minimum value of $90 \mathrm{mmHg}$ and a maximum value of $110 \mathrm{mmHg}$.

Based on the results, there is no significant difference on the data distribution of blood pressure on hypertension patients in the control group. It is caused due to lack of treatment as a factor in lowering blood pressure.

This study was supported by Ilham's research [10], the results in the control group illustrates that blood pressure in a group also decreased but not so significant. It was due to the respondents in control group also took hypertension drugs so that blood pressure decreased. Therefore, it would be more effective if they were given a treatment.

c. Distribution of blood pressure in the experimental groups before and after the treatment in patients with hypertension in the Working Area of Community Health Center 1 Sumbang.

In this study the finding shows that the systolic blood pressure prior to the treatment had a median value of $150 \mathrm{mmHg}$, a minimum value of $140 \mathrm{mmHg}$ and a maximum value of $180 \mathrm{~m} \mathrm{Hg}$, while the diastolic blood pressure prior to the treatment had a median value of 110 $\mathrm{mmHg}$, the minimum value of 100 and a maximum value of $120 \mathrm{mmHg}$.
The systolic blood pressure after the treatment had a median value of $130 \mathrm{mmHg}$, a minimum value of $120 \mathrm{mmHg}$ and a maximum value of $140 \mathrm{mmHg}$, while diastolic blood pressure had a median value of $90 \mathrm{mmHg}$, a minimum value of $80 \mathrm{mmHg}$ and a maximum value of $100 \mathrm{mmHg}$.

Based on these data we can see that there is a

difference in the blood pressure of hypertension patients in the working area of community health center 1 Sumbang before and after the treatment, especially in the experimental group. It indicates that there is an effect of feet soak using warm water with the mixture of ginger aromatherapy.

In general both men and women have the same possibility to suffer from hypertension in their lives. Yet, generally men have more risk of having hypertension compared to women at the age of 45 years and more. In contrary, at the age of 65 years and over, women are more at risk of having hypertension compared to men. It is associated with the elasticity of connective tissue, and reduction in the vascular smooth muscle relaxation, which in turn lowers the ability of distension and tensile strength of blood vessels [11].

d. The Effect of Feet Soaking with Warm Water with the Mixture of Ginger Aromatherapy

a. The effect in the control group

The systolic blood pressure in control group before and after the treatment had mean rank value of 3.50 with a $\mathrm{p}$-value $=0.414(\mathrm{p}>\alpha)$. The diastolic blood pressure before and after the treatment had mean rank value of 3.00 with $\mathrm{p}$-value $=0.739(\mathrm{p}>\alpha)$.

The results showed that there was no significant difference between the blood pressure before and after treatment in the control group. The results of this study had similar results to the study conducted by [12], which stated that there was no difference in the blood pressure value between the pretest and post-test on the patients with hypertension in the control group.

According to [13], the blood pressure is also influenced by the systemic and pulmonary circulation so that by having relaxation or meditation focusing on breathing arrangement the pulse will decrease and the blood pressure will drop.

According to the researchers, no significant change for the systolic blood pressure in the control group was caused by the absence of changes in the body system in an attempt to lower blood pressure. Blood pressure drops by several mechanisms and one of them is by 
nonpharmacological therapy. The conditions under which the researchers measured the blood pressure on day 1 had average blood pressure of $146 \mathrm{mmHg}$. It is due to several factors, one of which is age and gender. It continues to the seventh day of blood pressure measurement. The condition of their body is not given therapy as the experimental group so the respondents' blood vessels experience stiffness and increased blood pressure, As a consequence, the results of blood pressure is still high with an average of $144 \mathrm{mmHg}$.

b. The effect in the experimental group

The systolic blood pressure in the experimental group before and after intervention had a mean rank value of 5.50 with $p$-value $=0.004(p<\alpha)$. Diastolic blood pressure before and after the treatment had a

mean rank value of 5.50 with $\mathrm{p}$-value $=0.002(\mathrm{p}$ $<\alpha)$.

The results showed that there were significant differences on the blood pressure before and after treatment in the experimental group. This occurs due to heat transfer from the warm water to the blood vessels, causing vasodilation of blood vessels. The effect of aromatherapy is to be able to make someone feels relaxed and can reduce the activity of vasoconstriction of blood vessels, furthermore the blood flow runs smoothly so that it can lower blood pressure [14].

According to [15] aromatherapy will be sent to the brain and the message will be forwarded to the thalamus to identify the scent. The smell will be interpreted by a variety of neuronal cells and delivered to the limbic system and the hypothalamus to be processed in the form of electrical impulses. The limbic system has two parts, the hippocampus (a place of smell recognition and memory) and the amygdala, a place for the emotional control center so that it can improve mood and increase alpha waves in the brain that triggers the secretion of the hormone serotonin and endorphins.

This study had similar results to the study conducted by [11], [16], and [17] which say that there is a significant difference on the blood pressure before and after the treatment using foot soaking. The function of warm water is basically to increase the activity of the cell by flowing the energy through convection (flow through a liquid medium), causing dilation of blood vessels to improve blood circulation throughout the body that affect the decrease in blood pressure. e. The difference of blood pressure in hypertension patients before and after the treatment.

a. The difference of blood pressure before the treatment

The result of pre-test of systolic blood pressure in the control group had a mean rank value of 8.60 and one in the experimental group had a mean rank value of 12.40 with $p$-value $=0.113(p>\alpha)$ which means there was no significant difference in systolic blood pressure before the treatment between experimental group and control group. The result of pre-test of diastolic blood pressure in the control group had a mean rank value of 8.05 and one in the experimental group had a mean rank value of 12.95 with $\mathrm{p}$-value $=0.044(\mathrm{p}<\alpha)$ which means there was a difference of diastolic blood pressure before the treatment between experimental group and control group.

Based on the results of the study there was no significant difference of systolic blood pressure before the treatment between the control group and the experimental group due to the similar characteristics, a medical diagnosis of hypertension.

Hypertension is associated with age that causes arteriosclerosis from the major arteries, especially the aorta, and is a result of reduced flexibility. When the arteries thicken and become more stiff, arteries and aorta lose their adjustment ability. As someone grows older, the arteries lose their elasticity or flexibility and the blood pressure tends to increase. The prevalence among the elderly is high at approximately $40 \%$ with the mortality rate of approximately $50 \%$ over the age of 60 years [18].

Diastolic blood pressure in the control and experimental groups before the treatment had a significant difference because the blood vessels of the respondents had experienced atheroslerocis.

According to [13], in diastolic blood pressure associated with coronary circulation, if coronary artery experiences atherosclerosis, it will affect diastolic blood pressure.

Based on the above theory, the significant difference in diastolic blood pressure between the control group and the experimental group occurred due to the respondents' age that is mostly in the old age so that they experience atherosclerosis. As a result, there was no uniformity of blood pressure measurement because the blood vessels among respondents can't be recognized directly.

b. The differences of blood pressure after the treatment

The result of post-test of systolic blood pressure in the control group had a mean rank value of 14.60 and one in the experimental group posttest had a mean rank value 
of 6.40 with $\mathrm{p}$-value $=0.001(\mathrm{p}<\alpha)$. The diastolic blood pressure of post-test after the treatment in the control group had a mean rank value of 14.00 and one in the experimental group had a mean rank value of 7.00 with p-value of $0.005(\mathrm{p}<\alpha)$, which means there was a significant difference between systolic blood pressure and diastolic blood pressure in the control group and experimental group after the treatment.

This result occurs because of the different treatment between the control group and the experimental group. In the control group, the condition of the circulatory system in the body does not change or experience stimulation to decrease blood pressure. In addition, it is also due to the workload of the heart which is owned by the respondent that does not change. If compared with systolic blood pressure in the experimental group, the respondents were given a therapy of feet soaking using warm water and a mixture of ginger aromatherapy. As a result, it makes the respondents in the experimental group felt calm because of the aromatherapy given and the saggy of blood vessels due to the effect of warm water, so that the blood flow runs more smoothly. This treatment difference is what causes the differences in the blood circulation system of the respondents in both groups so that there is significant difference in blood pressure after given treatment to the respondents.

When aromatherapy of ginger essential oils was inhaled, molecules that easily volatile will bring an aromatic element such as geraniol and linalool to the top of the nose where the cilia arise from the receptor cells. When molecules attach to the cilia, an electrochemical message will be transmitted via the olfactory tract into the limbic system which will stimulate a person's memory and emotional responses. The hypothalamus that acts as a regulator emits the message that must be delivered to the brain. The received message is then converted into a compound electrochemical action that causes a calm and relaxed feeling and can increase blood flow and decreases cardiac work [19].

The result of this study is also supported by a research conducted by [20]. The result of $t$ independent of systolic blood pressure in the control group from posttest showed that the mean was 1.89 and one in the experimental group had a mean of 5.83 with a mean different value $=-3.944$ and $\mathrm{t}$ value $=-4.344$ and it is negative, which means no significant changes, with $\mathrm{p}$ value $=0.001$. It indicates that there is a significant difference on the decrease of systolic blood pressure in the control group and experimental group.

\section{CONCLUSIONS}

1. The majority of hypertension patients who became respondents aged 56-65 years and were dominated by female with $90 \%$.

2. The mean of the systolic blood pressure of pre-test in the control group had a median value of $145 \mathrm{mmHg}$, a minimum value of $130 \mathrm{mmHg}$ and a maximum value of $160 \mathrm{mmHg}$, while diastolic blood pressure had a median value of $100 \mathrm{mmHg}$, a minimum value of $90 \mathrm{mmHg}$ and a maximum value of $110 \mathrm{mmHg}$.

3. The mean of the systolic blood pressure of pre-test in the experimental group had a median value of $150 \mathrm{mmHg}$, a minimum value of $140 \mathrm{mmHg}$, and a maximum value of $180 \mathrm{mmHg}$, while diastolic blood pressure had a median value of $110 \mathrm{mmHg}$, a minimum value of $100 \mathrm{mmHg}$ and a maximum value of $120 \mathrm{mmHg}$.

4. The mean of the systolic blood pressure of post-test in the control group had a median value of $145 \mathrm{mmHg}$, a

minimum value of $130 \mathrm{mmHg}$ and a maximum value of 150 $\mathrm{mmHg}$, while diastolic blood pressure had a median value of $100 \mathrm{mmHg}$, a minimum value of $90 \mathrm{mmHg}$ and a maximum value of $110 \mathrm{mmHg}$.

5. The mean of the systolic blood pressure of post-test in the experimental group had a median value of $130 \mathrm{mmHg}$, a minimum value of $120 \mathrm{mmHg}$ and a maximum value of $140 \mathrm{mmHg}$, while diastolic blood pressure had a median value of $90 \mathrm{mmHg}$, a minimum value of $80 \mathrm{mmHg}$ and a maximum value of $100 \mathrm{mmHg}$.

6. The systolic blood pressure of pre-test and post-test in the control group had p-value $0.414(p>\alpha)$, while diastolic blood pressure had $p$-value $0.739(p>\alpha)$, which means that $\mathrm{HO}$ is accepted, hence there is no significant effect in reducing blood pressure.

7. The systolic blood pressure of pre-test and post-test in the experimental group had p-value of $0.004(\mathrm{p}<\alpha)$, while diastolic blood pressure had p-value of $0.002(p<\alpha)$ which means that $\mathrm{H} 0$ is rejected; hence there is a significant effect in lowering blood pressure.

\section{RECOMMENDATIONS}

1. It is expected that there are other researcher who develop further research about feet soaking with warm water using a mixture of ginger aromatherapy in lowering blood pressure. 
2. It is important to take into account other factors that might be done by respondents as an effort to lower the blood pressure independently which may not be recognized directly by the researchers.

3. It is essential to take into account the ease of access and execution of research including the location of giving the treatment.

4. If the research is carried out door to door, it will be much better to have researcher assistants who can reach out to all respondents in the adjacent time so that the data obtained is more valid.

\section{REFERENCES}

[1] World Health Organization, "A global brief on Hypertension - World Health Day 2013," World Heal. Organ., pp. 1-40, 2013.

[2] RISKESDAS, "Hasil Utama Riset Kesehatan Dasar 2018," Kementrian Kesehat. Republik Indones., 2018.

[3] Dinas Kesehatan Provinsi Jawa Tengah, "Profil Kesehatan Provinsi Jawa Tengah 2015," vol. 3511351, no. 24, pp. 1-261, 2015.

[4] Dinas Kesehatan Kabupaten Banyumas, "Profil Kesehatan Kabupaten Banyumas Tahun 2015," vol. 1, no. 1, pp. 1-180, 2015.

[5] P. . Poter and A. G. Perry, Fundamental Of Nursing 7 (Buku 2), 2009th ed. Jakarta: Salemba Medika, 2010.

[6] H. D. Setyaningrum and C. Saparinto, Jahe. Penebar Swadaya, 2013.

[7] Nursalam, "Metodologi Penelitian Ilmu Keperawatan: Pendekatan Praktis," Metodologi Penelitian Ilmu Keperawatan: Pendekatan Praktis. pp. 30-195, 2017.

[8] Y. I. Prasetyaningrum, Hipertensi Bukan Untuk Ditakuti. Fmedia, 2014.

[9] M. H. B. M. Arifin, I. W. Weta, and N. L. K. A. Ratnawati, "Faktor-Faktor Yang Berhubungan Dengan Kejadian Hipertensi Pada Kelompok Lanjut Usia Di Wilayah Kerja Upt Puskesmas Petang I Kabupaten Badung Tahun 2016," E-Jurnal Med. Udayana, vol. 5, no. 7, 2016.
[10] M. Ilham, Armina, and H. Kadri, "Efektivitas Terapi Relaksasi Otot Progresif Dalam Menurunkan Hipertensi Pada Lansia," J. Akad. Baiturrahim, vol. 8, no. 1, pp. 58-65, 2019.

[11] A. R. Nurahmandani, E. Hartati, and M. Supriyono, "Efektivitas Pemberian Terapi Rendam Kaki Air Jahe Hangat Terhadap Penurunan Tekanan Darah Pada Lansia Dengan Hipertensi Di Panti Werdha Pucang Gading Semarang," Ilmu Keperawatan Dan Kebidanan, 2016.

[12] Istiqomah and S. Salmiyati, "Pengaruh Hidroterapi Rendam Kaki Air Hangat Terhadap Tingkatan Tekanan Darah Pada Lansia Penderita Hipertensi Di Dusun Depok Ambarketawang Gamping Sleman Yogyakarta," Naskah Publ. Univ. 'Aisyiyah Yogyakarta, vol. 1, no. 3, pp. 1-13, 2017.

[13] J. Hermanto, "Pengaruh Meditasi Terhadap Penurunann Tekanan Darah Lansia Dengan Hipertensi di Unit Sosial Pucang Gading Semarang," J. Keperawatan, 2014.

[14] Z. Lalage, Hidup Sehat dengan Terapi Air. Abata Press, 2015.

[15] H. Susanto, "Pengaruh Aromaterapi Dalam Ruang Snoezelen Terhadap Kontrol Spastisitas Anak Cerebral Palsy Diplegi Di Yayasan Sayap Ibu Yogyakarta,”p. 10, 2014.

[16] M. Ulya, "Pengaruh Kombinasi Terapi Merendam Kaki Dengan Air Hangat Dan Inhalasi Aromaterapi Terhadap Tekanan Darah Pasien Hipertensi Di Desa Brabo Tanggungharjo Grobogan Jawa Tengah," 2017.

[17] I. E. Dilianti, E. Candrawati, and R. C. A. W., "Efektifitas hidroterapi terhadap penurunan tekanan darah lansia penderita hipertensi di Panti Wreda AlIslah Malang," Nurs. News (Meriden)., vol. 2, pp. 193-206, 2017.

[18] D. T. Elperin, M. A. Pelter, R. L. Deamer, and R. J. Burchette, "A Large Cohort Study Evaluating Risk Factors Associated With Uncontrolled Hypertension," J. Clin. Hypertens., vol. 16, no. 2, pp. 149-154, 2014.

[19] M. R. A. Saputra, Ernawati, and S. Fauzan, "Pengaruh Pemberian Aroma Terapi Bunga Mawar 
Terhadap Penurunan Tekanan Darah Pada Lanjut Usia Hipertensi Di Desa Sungai Bundung Laut Kabupaten Mempawah 2015,” 2015.

[20] Z. Zahrah, F. Aini, and Y. G. Yudanari, "Pengaruh Hidroterapi Rendam Kaki Menggunakan Air Hangat Terhadap Penurunan Tekanan Darah Pada Penderita Hipertensi Di Desa Nyatnyono Kecamsatan Ungaran Barat Kabupaten Semarang," 2016. 